\title{
Hubungan Faktor Sosio Ekonomi Dan Usia Kehamilan Dengan Kejadian Kekurangan Energi Kronis Pada Ibu Hamil Di Puskesmas Prambontergayang Kabupaten Tuban
}

\section{Correlation Between Socio Economic Factors and The Age of Pregnancy with the Incidence of Chronic Energy Deficiency among Pregnant Woman in Prambontergayang Public Health Center in Tuban Regency}

\author{
Fauziah Rizki Andini*1
}

\begin{abstract}
ABSTRAK
Latar Belakang : Kekurangan Energi Kronis dapat terjadi pada wanita usia subur (WUS) dan ibu hamil yang memiliki Lingkar Lengan Atas (LiLA) <23,5 cm. Pada tahun 2019 jumlah kejadian KEK ibu hamil di Puskesmas Prambontergayang melebihi target dari Kabupaten Tuban yaitu 10,8\%. Kejadian KEK terjadi karena tingkat pendidikan rendah, pengetahuan mengenai gizi rendah, pendapatan keluarga rendah, usia ibu $<20$ tahun atau $>35$ tahun, paritas ibu yang tinggi, dan jarak kehamilan yang terlalu dekat. Tujuan : untuk menganalisis faktor yang berhubungan dengan kejadian KEK pada ibu hamil di Puskesmas Prambontergayang Tahun 2019.

Metode: jenis penelitian yang digunakan adalah observasional analitik dengan menggunakan pendekatan cross sectional. Sampel dari penelitian yaitu ibu hamil di Puskesmas Prambontergayang yang berjumlah 179 ibu hamil yang dihitung menggunakan teknik simple random sampling. Variabel yang digunakan adalah usia, pendidikan, pekerjaan, penghasilan, dan usia kehamilan. Analisis data dilakukan menggunakan uji Chi Square dan Uji Pearson's.

Hasil: hasil penelitian menunjukkan bahwa prevalensi ibu hamil yang mengalami KEK sebesar $20,1 \%$ dan nilai p pada variabel usia $(p<0,0001)$, pendidikan $(p=0,013)$, pekerjaan $(p=0,008)$, dan penghasilan $(p<0,001)$ memiliki signifikasi $<0,05$ yang berarti terdapat hubungan dengan kejadian KEK. Pada variabel usia kehamilan, nilai $p>0,05$, yang berarti tidak ada hubungan dengan kejadian KEK.

Kesimpulan: kejadian KEK berhubungan dengan kondisi ibu hamil yang berusia $<20$ tahun dan $>35$ tahun, pendidikan rendah, tidak bekerja dan berpenghasilan rendah. Namun tidak ada hubungan antara usia kehamilan ibu dengan kejadian KEK. Saran yang dapat diberikan adalah pemerintah desa mengajak ibu hamil dan keluarganya untuk berpartisipasi aktif dalam mengelola ekonomi produktif dan Puskesmas memberikan sosialisasi mengenai makanan bergizi sehingga dapat meningkatkan pengetahuan ibu hamil.
\end{abstract}

Kata Kunci: KEK, ibu hamil, pendidikan, pekerjaan, usia

\section{ABSTRACT}

Background: Chronic Energy Deficiency can occur in women in reproductive age (WUS) and pregnant woman who have Mid Upper Arm Circumference (MUFA) $<23.5 \mathrm{~cm}$. In 2019 the number of occurrences of CED for pregnant women in Prambontergayang Public Health Center was exceeded the target of Tuban Regency by 10.8\%. Events of CED can occur due to low levels of education, low knowledge of nutrition, low family income, maternal age $<20$ years or 35 years, high maternal parity, and too close the pregnancy distance.

Purpose: to analyze factors related to the incidence of CED in pregnant women in the Prambontergayang Health Center in 2019. Method: this study was an observational analytic study with a cross sectional design. The sample of the study was pregnant women in Prambontergayang Public Health Center, which amounted to 179 pregnant women by using simple random sampling. The variables used are age, education, occupation, income, and age of pregnancy. Data analysis was performed using the Chi Square test and Pearson's Test.

Results: The results showed that the prevalence of pregnant women who experienced CED was $20.1 \%$ and the value of $p$ on the variables of age $(p<0.001)$, education $(p=0.013)$, occupation $(p=0.008)$, and income $(p<0.001)$ had significance $<0.05$ which meant 
there was a relationship with the CED events. In the gestational age variable, $p>0.05$, which means there was no relationship with the CED.

Conclusion: the incidence of CED is related to the condition of pregnant women aged $<20$ years and $>35$ years, low education, not working and low income. But there is no relationship between maternal gestational age with the incidence of CED. The advice that can be given is that the village government invites pregnant women and their families to actively participate in managing the productive economy and the Public Health Center provides information on nutritious foods so as to increase the knowledge of pregnant women.

Keywords: CED, pregnant woman, education, work, age

*Koresponden:

Email: fauziah.rizki.andini-2016@fkm.unair.ac.id

Fauziah Rizki Andini

Fakultas Kesehatan Masyarakat, Universitas Airlangga Kampus C, Mulyorejo, Surabaya-60115, Jawa Timur, Indonesia

\section{PENDAHULUAN}

Perdarahan, hipertensi, infeksi, partus lama, dan abortus merupakan penyebab terbesar dari kematian ibu selama tahun 2010 sampai dengan tahun $2013^{1}$. Dua puluh delapan persen (28\%) kematian ibu disebabkan oleh perdarahan. Kekurangan Energi Kronis (KEK) merupakan keadaan dimana ibu menderita kekurangan makanan yang berlangsung secara menahun (kronis) yang mengakibatkan timbunya gangguan kesehatan pada ibu. KEK dapat terjadi pada wanita usia subur (WUS) dan ibu hamil yang memiliki ukuran Lingkar Lengan Atas (LiLA) $<23,5 \mathrm{~cm}^{2}$. Prevalensi anemia dan Kekurangan Energi Kronis (KEK) pada kehamilan secara global 35-75\% terjadi pada trimester ketiga ${ }^{3}$.

Kekurangan Energi Kronis (KEK) pada Wanita Usia Subur(WUS) dan ibuhamil berisiko melahirkan Berat Bayi Lahir Rendah (BBLR) kurang dari 2500 gram $^{4,5}$. Hal ini dapat terjadi karena pada awal kehamilan, ibu hamil mengalami malnutrisi sehingga mempengaruhi perkembangan dan kapasitas embrio. Asupan nutrisi yang buruk dapat mempengaruhi pertumbuhan janin sehingga pertumbuhan janin tidak dapat maksimal, selain itu juga dapat menyebabkan daya tahan tubuh melemah dan mudah untuk terserang penyakit ${ }^{4}$. Beberapa penyebab yang dapat mempengaruhi Kekurangan Energi Kronis (KEK) adalah tingkat pendidikan rendah, pengetahuan mengenai gizi yang rendah, pendapatan keluarga yang rendah, usia ibu $<20$ tahun atau >35 tahun, paritas ibu yang tinggi, dan jarak kehamilan yang terlalu dekat ${ }^{6}$. Ibu hamil yang mengalami kekurangan gizi berisiko melahirkan bayi dengan berat badan rendah sebesar 2 sampai 3 kali lebih besar jika dibandingkan dengan ibu hamil yang tidak mengalami kekurangan gizi. Hal tersebut dapat berisiko bayi meninggal sebesar 1,5 kali lipat?.

Dampak kejadian Kekurangan Energi Kronis (KEK) terhadap ibu diantaranya adalah meningkatkan risiko terjadinya anemia, pendarahan, dan terkena penyakit infeksi ${ }^{8}$. Selain itu dampak Kekurangan Energi Kronis (KEK) terhadap proses persalinan diantaranya akan berisiko terjadinya persalinan lama, persalinan sebelum waktunya (prenature), dan persalinan dengan operasi cenderung meningkat ${ }^{9}$. Kejadian Kekurangan Energi Kronis (KEK) juga memiliki dampak terhadap janin diantaranya adalah berisiko terjadinya proses pertumbuhan janin terhambat, keguguran atau abortus, bayi lahir mati, kematian neonatal, cacat bawaan, anemia pada bayi, asfiksia intra partum (mati dalam kandungan), lahir dengan berat badan lahir rendah $(B B L R)^{10}$.

Pemerintah melakukan pelayanan kesehatan ibu hamil dengan harapan dapat menurunkan angka kematian ibu (AKI). Proses pelayanan tersebut dilakukan selama rentang usia kehamilan ibu yang dikelompokkan sesuai dengan usia kehamilan. Upaya pelayanan kesehatan tersebut harus memenuhi frekuensi minimal tiap trimesternya yang berfungsi untuk mencegah terjadinya masalah kesehatan khususnya yang berkaitan dengan status gizi ${ }^{11}$. Status gizi berkaitan dengan kesehatan fisik maupun kognitif, mempengaruhi tinggi rendahnya risiko terhadap penyakit infeksi maupun penyakit tidak menular dan berpengaruh sejak awal kehidupan hingga masa usia lanjut ${ }^{12}$.

Pada tahun 2018 proporsi risiko Kekurangan Energi Kronis (KEK) pada wanita usia subur (usia 15-49 tahun) di Indonesia adalah sebesar 17,3\%13. Namun pada tahun 2013 proporsi risiko KEK sebesar 24,2\%, sehingga pada tahun 2018 sudah mengalami penurunan. Pada tahun 2019 di wilayah kerja Puskesmas Prambontergayang Kecamatan Soko Kabupaten Tuban terdapat ibu hamil sejumlah 333 jiwa. Penelitian ini dilakukan di wilayah kerja tersebut karena jumlah kejadian KEK di wilayah tersebut melebihi standar yang ditentukan oleh Kabupaten Tuban yaitu sebesar 7,6\% namun pada kenyataannya sebanyak 10,8\% dari jumlah ibu hamil di wilayah tersebut mengalami Kekurangan Energi Kronis (KEK) ${ }^{14}$. Tujuan dalam penelitian ini adalah untuk menganalisis faktor yang berhubungan dengan kejadian Kekurangan Energi Kronis (KEK) pada ibu hamil di wilayah kerja Puskesmas Prambontergayang tahun 2019.

\section{METODE}

Pengambilan data dilakukan di Puskesmas Prambontergayang Kecamatan Soko Kabupaten Tuban. Penelitian ini merupapkan penelitian observasional analitik 
dengan desain cross sectional yang bertujuan untuk mengetahui faktor yang berhubungan dengan kejadian Kekurangan Energi Kronis (KEK) pada ibu hamil di wilayah kerja Puskesmas Prambontergayang tahun 2019.

Subyek dari penelitian hanya diobservasi satu kali dan pengukuran dilakukan terhadap status karakter atau variabelsubyek pada saat dilakukan pemeriksaan ANC. Populasi penelitian yakni seluruh ibu hamil yang ada di wilayah kerja Puskesmas Prambontergayang dengan jumlah sebanyak 333 orang. Dari sejumlah populasi tersebut diambil sampel yaitu sejumlah 179 ibu hamil dengan kriteria inklusi ibu hamil yang melakukan pemeriksaan ANC tahun 2019 di Puskesmas Prambontergayang. Pengambilan sampel dilakukan dengan menggunakan teknik Simple Random Sampling.

Teknik dan instrumen pengumpulan data menggunakan pita LiLA selama proses kegiatan ANC (Antenatal Care) yang dilakukan oleh bidan dan juga wawancara secara informal kepada responden mengenai karakteristik responden. Ibu hamil dapat dikatakan mengalami kekurangan energi kronis atau tidak ditentukan dengan ukuran Lingkar Lengan Ata (LiLA), KEK terjadi pada ibu hamil yang memiliki ukuran Lingkar Lengan Atas (LiLA) $<23,5 \mathrm{~cm}$. Analisis data dilakukan dengan menggunakan uji Chi Square dan Uji Pearson. Variabel yang digunakan adalah umur ibu, pendidikan, pekerjaan, penghasilan, dan usia kehamilan.

\section{HASIL DAN PEMBAHASAN}

Puskesmas Prambontergayang merupakan puskesmas yang memiliki wilayah kerja dengan jumlah desa sebanyak 10 desa. Pada tahun 2019 jumlah ibu hamil di wilayah kerja Puskesmas Prambontergayang adalah sebanyak 333 ibu hamil. Capaian kejadian Kekurangan Energi Kronis (KEK) di Puskesmas Prambontergayang pada tahun 2019 melebihi target yang telah ditentukan oleh Kabupaten Tuban yaitu sebesar 10,8\% dari target 7,6\%.

Berikut ini merupakan hasil dari penelitian di Puskesmas Prambontergayang tahun 2019 tentang faktor yang berhubungan dengan kejadian Kekurangan Energi Kronis (KEK) pada ibu hamil :

\section{Kekurangan Energi Kronis}

Kekurangan Energi Kronis merupakan salah satu dari keadaan malnutrisi. Apabila hasil dari pengukuran Lingkar Lengan Atas (LiLA) <23,5 $\mathrm{cm}$ maka berisiko mengalami kejadian KEK. Berdasarkkan Tabel 1. dapat diketahui bahwa diwilayah kerja Puskesmas Prambontergayang terdapat 20,1\% ibu hamil mengalami kejadian Kekurangan Energi Kronis (KEK). LiLA dapat digunakan untuk mengetahui risiko kejadian Kekurangan Energi Kronis (KEK) karena pada umumnya perempuan Indonesia tidak mengetahui berat badan pralahir dan relatif stabil sehingga IMT prahamil tidak dapat diukur ${ }^{15}$.

2. Usia
Semakin muda usia ibu hamil ( $<20$ tahun) maka membutuhkan jumlah asupan gizi yang banyak untuk pertumbuhan dan perkembangan dirinya sendiri dan juga janinnya. Sedangkan semakin tua usia ibu hamil (>35 tahun) juga mempengaruhi jumlah kebutuhan gizi, dimana ibu hamil dengan usia tua membutuhkan tambahan energi yang besar untuk mendukung kehamilannya. Melahirkan anak pada usia ibu yang muda atau terlalu tua dapat mengakibatkan kualitas janin atau anak yang rendah dan juga akan merugikan kesehatan ibu ${ }^{16}$.Berdasarkan tabel 1 dapat diketahui bahwa terdapat 44 orang $(24,6 \%)$ dikategorikan ke dalam umur yang berisiko mengalami KEK.

Tabel 1. Distribusi Frekuensi Variabel Penelitian

\begin{tabular}{lcc}
\hline Karakteristik & Frekuensi & Persentase (\%) \\
\hline KEK & & \\
Ya $(<23,5 \mathrm{~cm})$ & 36 & 20,1 \\
Tidak $(\geq 23,5$ & 143 & 79,9 \\
cm) & & \\
Usia & & \\
$\quad<20$ & 13 & 7,3 \\
$20-25$ & 51 & 28,5 \\
$26-30$ & 50 & 27,9 \\
$31-35$ & 34 & 19,0 \\
$36-40$ & 23 & 12,8 \\
$41-45$ & 6 & 3,4 \\
$46-50$ & 2 & 1,1 \\
Pendidikan & & \\
SD & 28 & 15,6 \\
SMP & 71 & 39,7 \\
SMA & 66 & 36,9 \\
D3/S1 & 14 & 7,8 \\
Pekerjaan & & \\
Tidak & 94 & 52,5 \\
Bekerja & & \\
Petani & 45 & 25,1 \\
Swasta & 35 & 19,6 \\
Guru & 5 & 2,8 \\
Penghasilan & & \\
Rendah & 178 & 0,6 \\
Tinggi & 1 & \\
Jumlah & 179 & \\
\hline
\end{tabular}

Hasil penelitian yang dilakukan di Puskesmas Prambontergayang menyebutkan bahwa sebesar $24,6 \%$ responden berada pada usia yang berisiko yaitu usia $<20$ tahun dan $>35$ tahun. Pada variabel usia nilai $\rho=0.000(\rho<0,05)$ yang memiliki arti bahwa variabel usia dapat mempengaruhi kejadian Kekurangan Energi Kronis (KEK) pada ibu hamil. Hal ini didukung oleh penelitian terdahulu yang menunjukkan bahwa terdapat pengaruh usia ibu dengan kejadian Kekurangan Energi Kronis (KEK). Semakin muda 
usia ibu hamil maka risiko mengalami kejadian KEK sebesar 2,761 kali lebih tinggi dibandingkan kategori usia lainnya ${ }^{17,18,19,20,21}$. Begitu sebaliknya, usia ibu hamil yang semakin tinggi maka semakin rendah mengalami risiko Kekurangan Energi Kronis (KEK). Kejadian Kekurangan Energi Kronis (KEK) lebih banyak terjadi pada usia ibu $<20$ tahun dan $>35$ tahun, paritas ibu yang tinggi atau terlalu sering hamil, dan jarak kelahiran yang terlalu dekat $^{5,22}$. Ibu yang memiliki usia $<20$ tahun secara psikologis belum mampu untuk menghadapi kehamilan karena masih terlalu muda. Sedangkan untuk ibu hamil yang berusia > 35 tahun akan berisiko kehamilan dengan kelainan bawaan. Hasil penelitian ini sesuai dengan penelitian terdahlu dimana hasil dari penelitian tersebut menyebutkan bahwa dari 27 responden terdapat
74,1\% mengalami KEK dan 25,9\% tidak mengalami KEK.

3. Pendidikan

Pendidikan ibu sering kali memiliki pandangan yang positif terhadap pengembangan pola konsumsu makanan dalam keluarga. Semakin tinggi pendidikan seseorang maka semakin mudah pula untuk menerima informasi sehingga semakin banyak pengetahuan yang dimilikinya. Sebaliknya jika seseorang tingkat pendidikannya rendah maka akan menghambat perkembangan sikap seseorang terhadap penerimaan informasi dan nilai-nilai baru yang diperkenalkan ${ }^{23}$. Mayoritas pendidikan responden adalah SMP yaitu sebesar 39,7\% sedangkan minoritas pendidikan responden adalah D3/S1 dengan persentase sebesar $7,8 \%$.

Tabel 2. Hubungan Variabel Usia, Pendidikan, Pekerjaan, dan Penghasilan dengan KEK Pada Ibu Hamil di Puskesmas Prambontergayang Tahun 2019

\begin{tabular}{|c|c|c|c|c|c|c|c|}
\hline \multirow[b]{2}{*}{$\begin{array}{l}\text { Usia Ibu } \\
\text { (tahun) }\end{array}$} & \multicolumn{4}{|c|}{ LiLA } & \multirow[b]{2}{*}{ Total } & \multirow[b]{2}{*}{$\begin{array}{c}\text { Persentase } \\
\text { (\%) }\end{array}$} & \multirow[b]{2}{*}{$\begin{array}{c}\rho \\
\text { value }\end{array}$} \\
\hline & KEK & Persentase (\%) & Tidak KEK & $\begin{array}{c}\text { Persentase } \\
\text { (\%) }\end{array}$ & & & \\
\hline$<20$ & 6 & 16,7 & 7 & 4,9 & 13 & 7,3 & \\
\hline $20-25$ & 13 & 36,1 & 38 & 26,5 & 51 & 28,5 & \\
\hline $26-30$ & 7 & 19,4 & 43 & 30,1 & 50 & 27,9 & \\
\hline $31-35$ & 8 & 22,2 & 26 & 18,2 & 34 & 19,0 & 0,000 \\
\hline $36-40$ & 0 & 0,0 & 23 & 16,1 & 23 & 12,8 & \\
\hline $41-45$ & 1 & 2,8 & 5 & 3,5 & 6 & 3,4 & \\
\hline $46-50$ & 1 & 2,8 & 1 & 0,7 & 2 & 1,1 & \\
\hline \multicolumn{8}{|l|}{ Pendidikan } \\
\hline SD & 5 & 13,9 & 23 & 16,1 & 28 & 15,6 & \multirow{4}{*}{0,013} \\
\hline SMP & 10 & 27,8 & 61 & 42,7 & 71 & 39,7 & \\
\hline SMA & 21 & 58,3 & 45 & 31,5 & 66 & 36,9 & \\
\hline D3/S1 & 0 & 0,0 & 14 & 9,8 & 14 & 7,8 & \\
\hline \multicolumn{8}{|l|}{ Pekerjaan } \\
\hline Tidak Bekerja & 28 & 77,8 & 66 & 46,2 & 94 & 52,5 & \multirow{4}{*}{0,008} \\
\hline Petani & 4 & 11,1 & 41 & 28,7 & 45 & 25,1 & \\
\hline Swasta & 3 & 8,3 & 32 & 22,4 & 35 & 19,6 & \\
\hline Guru & 1 & 2,8 & 4 & 2,8 & 5 & 2,8 & \\
\hline \multicolumn{8}{|l|}{ Penghasilan } \\
\hline Rendah & 36 & 100 & 142 & 99,4 & 178 & 99,4 & \multirow{2}{*}{0,000} \\
\hline Tinggi & 0 & 0,0 & 1 & 0.6 & 1 & 0,6 & \\
\hline
\end{tabular}

Ket : menggunakan uji chisquare karena uji chisquare digunakna untuk uji hubungan data kategorikan baik data nominal ataupun data ordinal

Hasil penelitian menunjukkan bahwa nilai $\rho=0.013$, hal ini menunjukkan bahwa variabel pendidikan memiliki hubungan dengan kejadian KEK pada ibu hamil di Puskesmas Prambontergayang. Hasil penelitian tersebut sejalan dengan penelitian terdahulu yang menyatakan bahwa terdapat hubungan antara pendidikan dengan kejadian KEK dengan nilai $\rho=$ $0,009^{24}$.

\section{Pekerjaan}

Pada variabel pekerjaan, mayoritas pekerjaan dari responden adalah tidak bekerja dengan persentase sebesar 52,5\%. Sedangkan minoritas responden bekerja sebagai guru dengan persentase sebesar 2,8\%. Pekerjaan seseorang berkaitan dengan ekonomi atau penghasilan yang dimilikinya yang dapat mempengaruhi kemampuan seseorang untuk memenuhi asupan gizinya. Hasil penelitian yang dilakukan di Puskesmas Prambontergayang menunjukkan bahwa terdapat hubungan antara 
pekerjaan dengan kejadian Kekurangan Energi Kronis (KEK) pada ibu hamil dengan nilai $\rho=0.008$ $(\rho<0,05)$. Hal ini sejalan dengan penelitian lain yang menyatakan bahwa terdapat pengaruh antara pekerjaan dengan kejadian Kekurangan Energi Kronis $(\mathrm{KEK})^{7,21}$. Namun terdapat penelitian yang tidak sejalan, penelitian tersebut menyebutkan bahwa tidak adanya hubungan bermakna antara pekerjaan dengan kejadian Kekurangan Energi Kronis (KEK) ${ }^{21}$.

\section{Penghasilan}

Pada variabel penghasilan dapat diketahui bahwa mayoritas penghasilan responden rendah dengan persentase sebesar 99,4\%. Variabel penghasilan dikategorikan berdasarkan Upah Minimum Kabupaten (UMK) Kabupaten Tuban yaitu sebesar Rp 2.333.641,85. Penghasilan dikatakan rendah jika kurang dari UMK, sedangkan penghasilan tinggi jika lebih dari UMK. Besar penghasilan yang diperoleh responden dapat mempengaruhi pola makan sehingga secara tidak langsung dapat mempengaruhi kondisi nutrizi ibu hamil dan bayinya. Semakin tinggi pendapatan keluarga maka akan semakin mampu pula keluarga tersebut untuk memenuhi asupan gizi yang baik. Begitu pula sebaiknya, semakin rendah pendapatan keluarga makan akan sulit untuk memenuhi nutrisi dan asupan gizi yang dibutuhkan oleh tubuh. Faktor ekonomi berhubungan dengan tingkat pendapatan dan melahirkan daya beli seseorang apabila tingkat pendapatan tersebut seimbang dengan jumlah anggota keluarga yang menjadi bebannya. Ibu yang memiliki ekonomi tinggi maka akan selalu berusaha untuk memenuhi kebutuhan keluarga dengan mengutamakan kualitasnya ${ }^{25}$. Hasil penelitian menunjukkan bahwa nilai $\rho=0,000$ $(\rho<0,05$. $) \mathrm{Hal}$ ini menunjukkan bahwa terdapat hubungan antara penghasilan dengan kejadian KEK di wilayah kerja Puskesmas Prambontergayang. Hasil tersebut sesuai dengan penelitian terdahulu yang menyatakan bahwa terdapat hubungan antara penghasilan dengan kejadian Kekurangan Energi Kronis (KEK) pada ibu hamil ${ }^{17,26,27 .}$ Prambontergayang

\begin{tabular}{|c|c|c|c|c|c|}
\hline & & \multicolumn{2}{|c|}{ KEK } & \multirow[t]{2}{*}{ Total } & \multirow[t]{2}{*}{$P$ value } \\
\hline & & KEK & Tidak KEK & & \\
\hline \multirow{26}{*}{ UsiaKehamilan } & 4,0 & 1 & 2 & 3 & \multirow{26}{*}{0,224} \\
\hline & 5,0 & 0 & 1 & 1 & \\
\hline & 6,0 & 1 & 5 & 6 & \\
\hline & 7,0 & 0 & 3 & 3 & \\
\hline & 8,0 & 1 & 37 & 38 & \\
\hline & 10,0 & 2 & 0 & 2 & \\
\hline & 11,0 & 1 & 0 & 1 & \\
\hline & 12,0 & 4 & 22 & 26 & \\
\hline & 13,0 & 0 & 1 & 1 & \\
\hline & 14,0 & 1 & 0 & 1 & \\
\hline & 15,0 & 1 & 4 & 5 & \\
\hline & 16,0 & 4 & 3 & 7 & \\
\hline & 18,0 & 1 & 0 & 1 & \\
\hline & 19,0 & 1 & 0 & 1 & \\
\hline & 20,0 & 5 & 13 & 18 & \\
\hline & 21,0 & 0 & 1 & 1 & \\
\hline & 23,0 & 0 & 2 & 2 & \\
\hline & 24,0 & 3 & 14 & 17 & \\
\hline & 25,0 & 0 & 1 & 1 & \\
\hline & 26,0 & 1 & 1 & 2 & \\
\hline & 27,0 & 1 & 0 & 1 & \\
\hline & 28,0 & 2 & 0 & 2 & \\
\hline & 29,0 & 1 & 5 & 6 & \\
\hline & 30,0 & 1 & 13 & 14 & \\
\hline & 31,0 & 0 & 3 & 3 & \\
\hline & 32,0 & 1 & 6 & 7 & \\
\hline
\end{tabular}




\begin{tabular}{|c|c|c|c|c|c|}
\hline & & & & Total & $P$ value \\
\hline & & KEK & Tidak KEK & & \\
\hline & 33,0 & 0 & 1 & 1 & \\
\hline & 34,0 & 1 & 2 & 3 & \\
\hline & 35,0 & 2 & 1 & 3 & \\
\hline & 36,0 & 0 & 1 & 1 & \\
\hline & 39,0 & 0 & 1 & 1 & \\
\hline Total & & 36 & 143 & 179 & \\
\hline
\end{tabular}

Ket: uji pearson digunakan uji hubungan dengan data berskala interval/rasio yang berdistribusi normal

6. Usia Kehamilan

Usia kehamilan terbagi menjadi 3 trimester. Trimester pertama adalah 1-13 minggu, trimester kedua dimulai pada minggu ke-14 dan berakhir di usia kandungan 27 minggu. Sedangkan, trimester ketiga dimulai pada 28 minggu sampai kehamilan minggu ke-41 atau waktu melahirkan. Pada penelitian ini, mayoritas responden memiliki usia kehamilan yaitu 8 minggu yang termasuk dalam trimester pertama yaitu sebesar $21,1 \%$. Hasil dari penelitian menunjukkan bahwa nilai $\rho=0,224$ dimana nilai $\rho$ tersebut lebih besar dari 0,05 yang berarti tidak terdapat hubungan antara usia kehamilan dengan kejadian Kekurangan Energi Kronis (KEK) pada ibu hamil di wilayah kerja Puskesmas Prambontergayang tahun 2019. Usia kehamilan tidak berhubungan dengan kejadian Kekurangan Energi Kronis (KEK) karena KEK dapat terjadi pada ibu hamil yang kehamilannya berusia pada trimester pertama, kedua, ataupun ketiga. Hasil dari penelitian ini sejalan dengan hasil penelitian terdahulu bahwa $87,3 \%$ responden tidak mengalami Kekurangan Energi Kronis (KEK) dalam masa kehamilan ${ }^{25}$.

\section{KESIMPULAN}

Berdasarkan hasil penelitian dan pembahasan, maka dapat disimpulkan bahwa kejadian Kekurangan Energi Kronis (KEK) berhubungan dengan kondisi ibu hamil yang berusia $<20$ tahun dan $>35$ tahun, pendidikan rendah, tidak bekerja dan memiliki penghasilan yang rendah. Hasil penelitian menyebutkan bahwa tidak ada hubungan yang bermakna antara usia kehamilan ibu dengan kejadian Kekurangan Energi Kronis (KEK) pada ibu hamil di wilayah kerja Puskesmas Prambontergayang Tahun 2019. Berdasarkan hasil penelitian tersebut, maka saran yang dapat diberikan adalah pemerintah desa Prambontergayang dapat mengajak atau mengikutsertakan ibu hamil dan keluarganya untuk berpartisipasi aktif dalam mengelola ekonomi produktif sehingga penghasilan keluarga meningkat, selain itu pemerintah desa Prambontergayang juga dapat menambah anggaran untuk pemberian makanan yang bergizi kepada ibu hamil selama ada kegiatan ANC. Puskesmas Prambontergayang dapat memberikan sosialisasi kepada ibu hamil mengenai makanan bergizi sehingga pengetahuan ibu hamil dapat meningkat dan kejadian Kekurangan Energi Kronis (KEK) dapat dicegah.

\section{ACKNOWLEDGEMENT}

Terima kasih kepada Puskesmas Prambontergayang karena telah memberikan saya izin untuk menganalisis data mengenai kondisi lbu Hamil di Wilayah Kerja Puskesmas Prambontergayang.

\section{REFERENSI}

1. Kemenkes, R. Profil Kesehatan Indonesia 2014. (2015).

2. Departemen Kesehatan RI. Kekurangan Energi Kronis. (2012).

3. Rukiah, A. Y. Asuhan Kebidanan. (TIM, 2010).

4. Atikah Proverawati, S., \& Siti Asfufah, S. Buku Ajar Gizi Untuk Kebidanan. (Nuha Medica, 2009).

5. Supariasa, I.D.N., Bakri, B., Fajar, I. Penilaian Status Gizi. (EGC, 2016).

6. Arisman, M. Gizi dalam Daur Kehidupan. (EGC, 2009).

7. Andriani, Z. Gambaran Status Gizi Ibu Hamil Berdasarkan Ukuran Lingkar Lengan Atas (Lila) Di Kelurahan Sukamaju Kota Depok. Skripsi Fak. Kedokt. Dan Ilmu Kesehat. Uin Syarif Hidayatullah Jakarta 1-98 (2015).

8. Irianto, K. Ilmu Kesehatan Masyarakat. (Alfabeta, 2014).

9. Agria, R. Gizi Reproduksi. (Fitramaya, 2012).

10. Waryana. Gizi Reproduksi. (Pustaka Rahima, 2010).

11. Syukur, N. Faktor-Faktor yang Menyebabkan Kurang Energi Kronis (KEK) pada Ibu Hamil di Puskesmas Sidomulyo Kota Samarinda. Mahakam Midwifery J. 1, 38-45 (2016).

12. Kemenkes, R. Profil Kesehatan Indonesia Tahun 2015. (2016).

13. Kemenkes. Hasil Utama Riskesdas 2018. (2018).

14. Profil Puskesmas Prambontergayang. (2018).

15. Ariyani, E,D., Achadi, E.L., Irawati, A. Validitas Lingkar Lengan Atas Mendeteksi Risiko Kekurangan Energi Kronis pada Wanita Indonesia. J. Kesehat. Masy. Nas. 7, 83-90 (2012).

16. Kusmiati, Y. Perawatan Ibu Hamil (Asuhan Ibu Hamil). (Pitramaya, 2008).

17. Rahmi, L. Faktor-Faktor Yang Berhubungan 
Dengan Kekurangan Energi Kronik (Kek) Pada Ibu Hamil Di Puskesmas Belimbing Padang Factors Related To Chronic Energy Deficiency (Ced) To Pregnant Woman in Belimbing Health Centre Padang. J. Kesehat. Med. Saintika 8, 35-46 (2016).

18. Sukmawati, Mamuroh, L. \& Witdiawati3. Faktor yang Berhubungan Dengan Kekurangan Energi. J. Keperawatan BSI VI, 1-11 (2018).

19. Handayani $S$ \& Budianingrum S. Analisis Faktor Yang Mempengaruhi Kekurangan Energi Kronis Pada Ibu Hamil Di Wilayah Puskesmas Wedi Klaten. J. Ilmu Kebidanan 1, 42-46 (2015).

20. Mahirawati, V. related Factors of chronic Energy Deficiency at Pregnant Woman in kamoning and Tambelangan Sub $f$

21. Abraham, S., Miruts, G. \& Shumye, A. Magnitude of chronic energy deficiency and its associated factors among women of reproductive age in the Kunama population, Tigray, Ethiopia, in 2014. BMC Nutr. 1, 1-9 (2015).

22. Nurdin M.S., Haju V., Thahrir. A. I. . Determinants of Chronic Energy Deficiency among pregnant women in Jeneponto regency. Soc. Determ. Heal. 4, 3-11 (2018).

23. Notoatmodjo. Metodologi Penelitian Kesehatan. (Rineka Cipta, 2005).

24. Handayani, S \& Husna, H, P. Faktor Yang Mempengaruhi Kejadian Kurang Energi Kronis Pada Ibu Hamil (Studi Analitik Di Puskesmas Baturetno Kabupaten Wonogiri). J. Keperawatan GSH 4, (2015).

25. Febriyeni. Faktor - Faktor Yang berhubungan Dengan Kejadian Kekurangan Energi Kronis Pada Ibu Hamil. J. Hum. Care 2, (2017).

26. Anggraini, Y. Pengaruh Demografi dan Sosioekonomi pada Kejadian Kekurangan Energi Kronik Ibu Hamil di Kota Metro Provinsi Lampung. J. Kesehat. 4, 401-408 (2016).

27. Lubis, L. Faktor-Faktor yang Berhubungan dengan Kejadian Kekurangan Energi Kronis (KEK) pada Ibu Hamil di Puskesmas Langsa Lama Kota Langsa Tahun 2015. J. Gizi, Kesehat. Reproduksi dan Epidemiol. 1, (2015). 